ISSN 2442-5419 Vol. 4, No. 2 (2015) 42-52

\title{
ANALISIS KESALAHAN SISWA SMP KELAS VIII DALAM \\ MENYELESAIKAN MASALAH SOAL CERITA \\ MATEMATIKA
}

\author{
Nurul Farida \\ Pendidikan Matematika FKIP Universitas Muhammadiyah Metro \\ E-mail: nurulfarida.maniz@yahoo.com
}

\begin{abstract}
The aims of the research is to know mistakes and cause of mistakes mengetahui were done by students in in troubleshoot mathematics story problem. The research was a descrptive qualitative. The subjects of the research was students of class VIII SMP Negeri 2 Karang Anyar. The result of the research are: 1) the mistakes made by students are: student incorrecting to change information that is given into mathematics expression, students can't determine formula, the students incorrectly concept, errors in interpreting the solution, do not make conclusions, errors in calculation; 2) cause students make mistakes are : do not pay attention to a matter of intent , forget the formula, less familiar to a material, less given the questions varied, in a hurry, and less conscientious in performing the calculations.
\end{abstract}

Keywords: analysis, mathematics story problem, mistake.

\section{PENDAHULUAN}

Selama ini pandangan bahwa matematika merupakan pelajaran yang sangat menakutkan masih belum berubah. Hal ini karena siswa banyak mengalami kesulitan untuk mempelajari matematika yang objek kajiannya abstrak. Sebagaimana diungkapkan oleh Soedjadi (2000:

13) mengemukakan karakteristik matematika, yakni:

1. Memiliki objek kajian yang abstrak.

2. Bertumpu pada kesepakatan.

3. Berpola pikir deduktif.

4. Memiliki simbol yang kosong dari arti.
5. Memperhatikan semesta pembicaraan.

6. Konsisten dalam sistemnya.

Carraher (2008)

menyatakan bahwa mathematics has contributed in important ways to long-standing debates about mathematical concepts, symbolic representation, and the role of contexts in thinking. Matematika berkenaan dengan konsep, representasi simbol, dan aturan dalam konteks berpikir manusia. Lebih lanjut Uno (2011: 129) mengungkapkan bahwa matematika sebagai ilmu yang merupakan alat pikir dan alat untuk memecahkan berbagai 
persoalan praktis yang didalamnya membutuhkan analisis dan logika berpikir seseorang.

Kesulitan juga banyak dialami siswa dalam menyelesaikan masalah yang berkenaan dengan soal cerita. Beberapa penelitian mengenai masalah menyelesaikan soal cerita matematika yaitu penelitian yang dilakukan oleh Putri (2008), terungkap bahwa kesulitan yang sering dialami siswa seperti 1) Tidak paham konsep-konsep sederhana 2) Tidak mengetahui maksud soal, 3) Tidak bisa menerjemahkan soal ke dalam kalimat matematika, 4) Tidak bisa menyelesaikan kalimat matematika, 5) Tidak cermat dalam menghitung, 6) Kesalahan dalam menulis angka.

Berdasarkan data PISA tahun 2009 dalam Ariyadi Wijaya (2012: 1-2), diperoleh hasil bahwa hampir setengah siswa Indonesia $(43,5 \%)$ tidak mampu menyelesaikan soal PISA paling sederhana. Sekitar sepertiga siswa Indonesia yaitu $(33,1 \%)$ hanya bisa mengerjakan soal dari soal kontekstual diberikan secara eksplisit serta semua data yang dibutuhkan untuk mengerjakan soal diberikan secara tepat. Hanya $0,1 \%$ siswa Indonesia mampu mengembangkan dan mengerjakan pemodelan matematika yang menuntut keterampilan berpikir dan penalaran.

Berdasar pada data tersebut dapat disimpulkan bahwa kemampuan siswa Indonesia dalam mengidentifikasi dan memahami peran matematika dalam kehidupan masih sangat rendah.

Masalah dalam matematika memiliki beberapa definisi. Menurut Dewiyani (2008: 2), masalah dalam matematika adalah pertanyaan atau soal yang harus dijawab atau direspon. Sejalan dengan pendapat tersebut, Herman Hudojo (2005: 69) menyatakan bahwa masalah dalam matematika yang disajikan seharusnya adalah masalah yang kontekstual dimana pertanyaan yang diberikan sesuai dengan pengalaman siswa

Berdasarkan pendapat di atas, masalah adalah suatu pertanyaan dimana pertanyaan tersebut merupakan tantangan bagi individu dan untuk menjawabnya diperlukan prosedur yang tidak biasa dilakukannya sehingga memerlukan penalaran berpikir yang lebih mendalam dari apa yang telah diketahuinya.

Mencermati uraian di atas, perlu dilakukan upaya untuk mendeskripsikan kesalahan-kesalahan siswa dalam menyelesaikan masalah soal cerita. Kesalahan dalam menyelesaikan soal matematika dapat dimanfaatkan untuk mendeteksi kesulitan belajar matematika sehingga dapat menemukan alternatif pemecahannya dalam menyelesaikan masalah soal cerita matematika. 


\section{METODE PENELITIAN}

Penelitian ini tergolong dalam penelitian deskriptif kualitatif yang bertujuan untuk mendeskripsikan kesalahan dan penyebab kesalahan siswa dalam memecahkan masalah soal cerita matematika. Data penelitian ini berupa jawaban tertulis dan lisan yang diperoleh dari tes tertulis dan wawancara. Subjek penelitian ini adalah siswa kelas VIII SMP N 2 Karang Anyar yang terdiri dari 3 siswa yang mampu memberikan informasi terkait dengan kesalahan dalam penyelesaian masalah matematika. Instrumen tes berupa tes tertulis yang memuat tiga butir soal

\section{HASIL PENELITIAN DAN PEMBAHASAN}

Tabel 1. Diskripsi Kesalahan Jawaban Siswa Soal Nomor 1

\begin{tabular}{|l|c|}
\hline \multicolumn{1}{|c|}{ Diskripsi Kesalahan Siswa } & Nomor subyek \\
\hline $\begin{array}{l}\text { Kesalahan mengubah informasi ke dalam ungkapan matematika } \\
\text { yaitu 1/10 dari sekarung beras }\end{array}$ & 2 \\
\hline $\begin{array}{l}\text { Salah dalam mengartikan keuntungan atau kerugian dalam } \\
\text { rupiah }\end{array}$ & 3 \\
\hline $\begin{array}{l}\text { Kesalahan dalam menentukan langkah penyelesaian yaitu } \\
\text { memahami banyaknya beras yang dijual ibu. }\end{array}$ & $1,2,3$ \\
\hline $\begin{array}{l}\text { Tidak (kesalahan) membuat kesimpulan atau pengembalian pada } \\
\text { permasalahan yang sebenarnya }\end{array}$ & \\
\hline
\end{tabular}

Tabel 2. Diskripsi Kesalahan Jawaban Siswa Soal Nomor 2

\begin{tabular}{|l|c|}
\hline \multicolumn{1}{|c|}{ Diskripsi kesalahan Siswa } & Nomor subyek \\
\hline $\begin{array}{l}\text { Kesalahan dalam menafsirkan solusi } \\
\text { (Yang diminta soal dalam rupiah tetapi menjawab dalam persen) }\end{array}$ & 1 \\
\hline Salah memahami bunga perbulan jika diketahui pertahun. & 2 \\
\hline $\begin{array}{l}\text { Kesalahan dalam memahami persentase, } \\
\text { dan mengartikan 12,5\% menjadi pecahan biasa. }\end{array}$ & 3 \\
\hline $\begin{array}{l}\text { Tidak (kesalahan) membuat kesimpulan atau pengembalian pada } \\
\text { permasalahan yang sebenarnya }\end{array}$ & $1,2,3$ \\
\hline
\end{tabular}


ISSN 2442-5419 Vol. 4, No. 2 (2015) 42-52

Tabel 3. Diskripsi Kesalahan Jawaban Siswa Soal Nomor 3

\begin{tabular}{|l|c|}
\hline \multicolumn{1}{|c|}{ Diskripsi kesalahan Siswa } & Nomor subyek \\
\hline Tidak menuliskan rumus bruto dan tara & $1,2,3$ \\
\hline Tidak dapat mengubah informasi ke dalam ungkapan matematika & $1,2,3$ \\
\hline $\begin{array}{l}\text { Tidak (kesalahan) membuat kesimpulan atau pengembalian pada } \\
\text { permasalahan yang sebenarnya }\end{array}$ & $1,2,3$ \\
\hline
\end{tabular}

\section{Jawaban tertulis dan wawancara subyek 1}

a. Jawaban no 1 dan 2

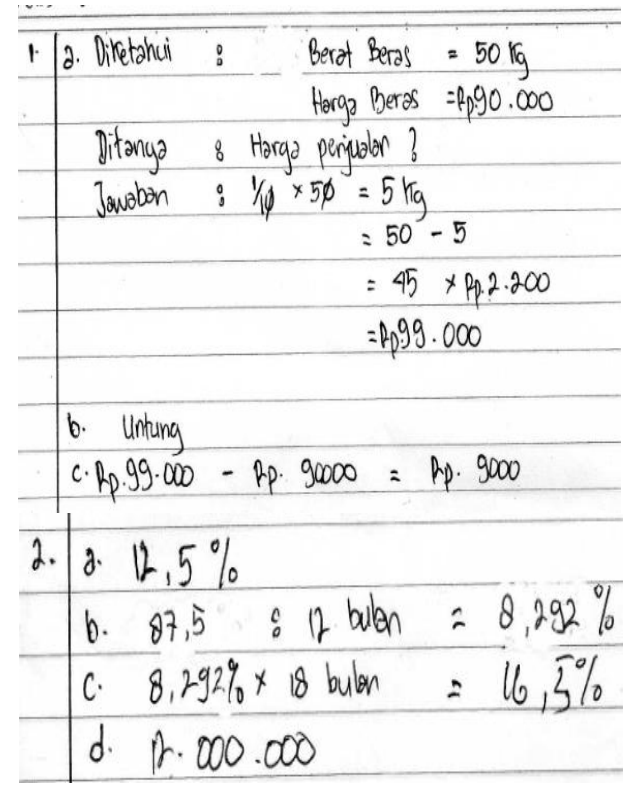

\section{Analisis kesalahan}

Kesalahan yang dilakukan oleh subyek 1 untuk soal nomor 1 adalah tidak mengembalikan jawaban ke permasalahan awal. Selanjutnya untuk soal nomor 2 adalah tidak memahami apa yang ditanyakan dalam soal yakni menjawab bunga dalam bentuk persen sedangkan pertanyaan dalam rupiah.

\section{Wawancara}

P: Havid, Jawabnya sudah benar, kesimpulannya harus ditulis ya supaya jelas apa yang ditanyakan."

S:"Iya, Bu. Saya males nulis kesimpulannya soalnya panjang $\mathrm{Bu}$.

P : "Kalau nomor 2 apa yang ditanyakan?"

S : "Bunga Bu."

P : "Coba perhatikan bunga nya dalam rupiah atau persen?"

$\mathrm{S}$ : "Oh iya, Bu, dalam rupiah."

P : "Trus kenapa Havid jawabnya dalam persen?"

$\mathrm{S}$ : "iya $\mathrm{Bu}$, saya gak

memperhatikan soalnya."

Berdasarkan wawancara di atas, diketahui bahwa penyebab subyek mengalami kesalahan dalam menjawab soal nomor 1 karena malas untuk membuat kesimpulan dan cenderung ingin menyingkat jawaban. Sedangkan nomor 2 adalah tidak memperhatikan apa yang ditanyakan dalam soal dan terburu-buru dalam mengerjakan. 
ISSN 2442-5419 Vol. 4, No. 2 (2015) 42-52

b. Jawaban tertulis soal nomor 3

\begin{tabular}{|c|c|}
\hline 3. & Diketahui: Berot5 $\begin{aligned} \text { raleng susu } & =6 \mathrm{rg} \\
& =1 \mathrm{Ka}\end{aligned}$ \\
\hline & - brita 8 tan? \\
\hline & Jawabon: bruto $=6-1$ \\
\hline & $=5 \mathrm{rg}$ \\
\hline & $=5+1$ \\
\hline & $100 \%$ \\
\hline & $=6$ \\
\hline & $\widehat{100 \%}$ \\
\hline & $=6 \%$ \\
\hline
\end{tabular}

\section{Analisis kesalahan}

Kesalahan yang dilakukan subyek 1 pada soal nomor 3 adalah tidak menuliskan rumus bruto dengan benar, tidak dapat mengubah informasi yang diberikan ke dalam ungkapan matematika, dan tidak menuliskan kesimpulan.

\section{Wawancara}

P : "Havid nomor 3 apa yang diketahui?"

S : "Berat, Bu."

P : "Berat apa?"

S : "Berat seluruh kaleng."

P : "Kalo seluruh berarti apa?"

$\mathrm{S}$ : "Gak tau $\mathrm{Bu}$, saya lupa pengertian bruto netto kayak gitu."

P : "Trus kenapa jawabnya begini?"

$\mathrm{S}$ : "Saya asal $\mathrm{Bu}$, soalnya saya lupa. Jadi langsung saya kurang aja."

Berdasarkan wawancara di atas, diketahui bahwa penyebab subyek melakukan kesalahan dalam menjawab soal nomor 3 adalah tidak memahami maksud soal dan lupa untuk mencari rumus bruto dan tara.

\section{Jawaban tertulis dan wawancara subyek 2}

a. Jawaban soal nomor 1

\section{Analisis Kesalahan}

Kesalahan yang dilakukan Subyek 2 adalah dalam memahami sepersepuluh dari sekarung beras.

\section{Wawancara}

P: 'Faiz, kenapa ko' jawabanya ibu mengalami kerugian?"

$\mathrm{S}$ : "Lha saya hitung yang (a) saya hasilnya rugi tuh $\mathrm{Bu}$."

P: "Coba lihat yang (a), pertanyaannya adalah sepersepuluh dari sekarung beras. Kalo Faiz jawabnya sepersepuluh dari apa?

$\mathrm{S}$ : "oh iya $\mathrm{Bu}$, dari harga saya jawabnya."

Berdasarkan wawancara di atas, diketahui bahwa penyebab subyek melakukan kesalahan dalam menjawab soal nomor 1 adalah tidak memperhatikan dengan cermat apa yang diketahui dalam soal. Meskipun langkah (b) 
dan (c) sudah mengerti caranya namun karena dalam (a) salah sehingga (b) dan (c) juga salah.

b. Jawaban soal no 2

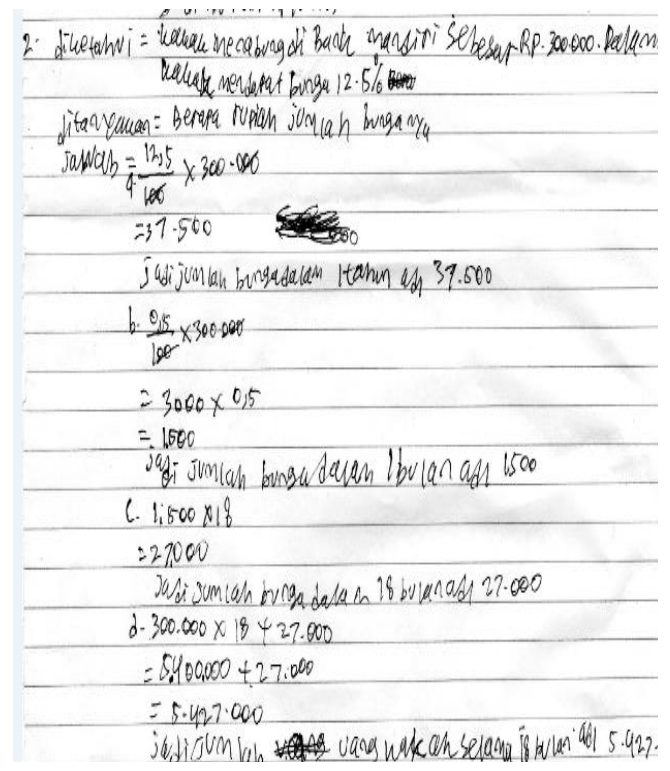

\section{Analisis kesalahan}

Jawaban subyek 2 untuk soal nomor 2 adalah pada poin (b,c,d). Kesalahan yang dilakukan pada (b) adalah dalam menulis persentase bunga 1 bulan sebesar 0,5 kemudian dikalikan dengan modal. Untuk (c), karena hasil pada (b) salah sehingga apa yang ia dapatkan pada poin (c) juga salah.

\section{Wawancara}

P : "Faiz, coba lihat jawaban no 2 yang (b), itu dapat $0,5 / 100$ dari mana?'

$\mathrm{S}$ : "Dari 12,5-12 Bu, setahu saya kan yang ditanya 1 bulan, jadi saya kurang $12 . "$
P : "Memang biasanya dikasih soalnya seperti apa? Bukan seperti ini?"

$\mathrm{S}$ : "Biasanya ya langsung ditanya jumlah tabungan selama satu tahun itu Bu."

$\mathrm{P}$ : "Kalau yang (d) gimana? Kenapa bisa dapatnya seperti ini?

S : "Seluruhnya sama bunganya saya kali $18 \mathrm{Bu} . "$

Berdasarkan petikan wawancara di atas, diketahui bahwa penyebab subyek melakukan kesalahan dalam menjawab soal nomor 2 adalah kurang pahamnya dalam menghitung bunga perbulan jika diketahui pertahun karena dalam pembelajaran kurang diberikan soal-soal yang bervariasi mengenai perhitungan bunga.

c. Jawaban tertulis soal No 3

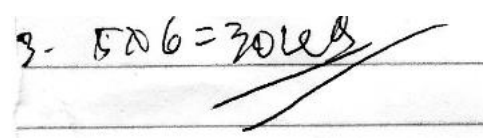

\section{Analisis kesalahan}

Kesalahan yang dilakukan subyek 2 pada soal nomor 3 adalah tidak menuliskan apa yang diketahui dan apa yang ditanyakan soal. Dia hanya menuliskan jawaban yang juga hasilnya salah.

\section{Wawancara}

P: "Faiz, kenapa kok jawabanya tidak ada diketahui dan ditanyakan?"

$\mathrm{S}$ : "iya Bu, lupa." 
$P$ : "Trus dapat jawaban 5x6 dari mana?"

S: "Hee. Saya ngasal Bu, soalnya saya lupa Bruto dan Tara."

Berdasarkan petikan wawancara di atas, diketahui bahwa penyebab kesalahan yang dilakukan subyek dalam menjawab soal nomor 3 adalah karena lupa, tidak memahami maksud soal dan lupa pengertian dan rumus bruto dan tara.

\section{Jawaban tertulis dan Wawancara Subyek 3 \\ a. Jawaban Soal No1}

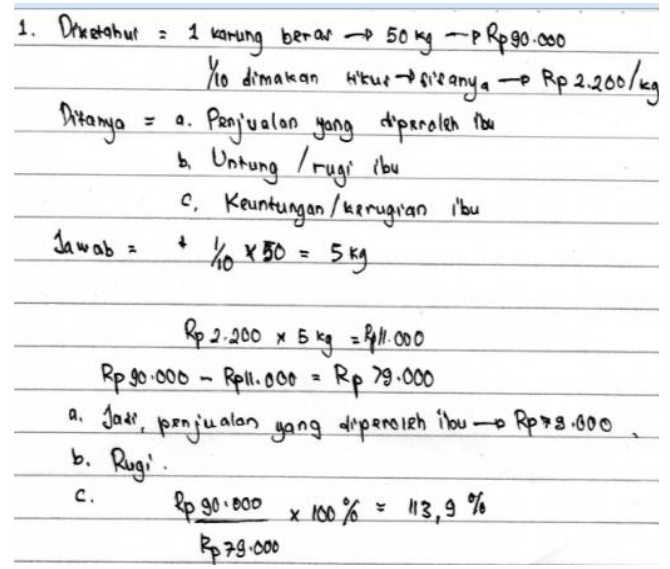

\section{Analisis kesalahan}

Kesalahan yang dilakukan oleh subyek 3 untuk soal nomor 1 adalah kesalahan dalam memahami maksud soal (kesalahan dalam mengartikan sepersepuluh yang dimakan tikus) yakni mengalikan harga dengan beras yang dimakan tikus bukan dengan sisa berasnya dan kesalahan dalam menghitung untung dan rugi.

\section{Wawancara}

P : "Lynda, apa yang ditanyakan untuk soal nomor 1 (a)?"

$\mathrm{S}$ : "Penjualan yang diperoleh Ibu."

P : "Trus, yang diketahui soal apa?"

S : "Sepersepuluh dari sekarung beras dimakan tikus."

P : "Berarti sepersepuluh dikali 50 lynda hasilnya sudah benar. Berati sisanya tinggal berapa?"

$\mathrm{S}$ : "Oh iya denk Bu. Saya lupa gak dikurangi."

P : "Iya, coba perhatikan yang (c) yang ditanya adalah berapa rupiah keuntungan yang diperoleh Ibu, bukan dalam persen."

$\mathrm{S}$ : "iya $\mathrm{Bu}$, saya tidak lihat lagi yang ditanyakan."

Berdasarkan petikan wawancara di atas, diketahui bahwa penyebab subyek melakukan kesalahan dalam menjawab soal nomor 1 adalah lupa dan tidak teliti dalam mengerjakan soal.

\section{b. Jawaban Soal No 2}

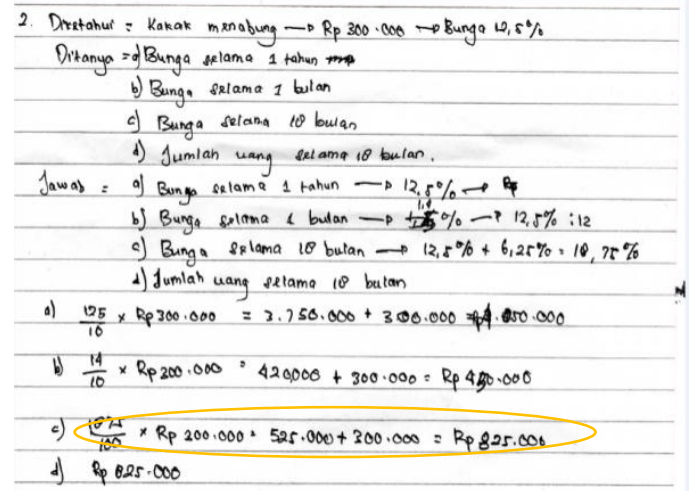




\section{Analisis kesalahan}

Kesalahan yang dilakukan oleh subyek 3 untuk soal nomor 2 adalah salah mengubah persen ke pecahan biasa. Subyek memahami bahwa $12,5 \%=125 / 10$ dan $1,4 \%=$ $14 / 10$, serta $18,75 \%=1875 / 100$.

\section{Wawancara}

P : "Erlynda, 12,5\% itu sama dengan 125/10 cara gimana?"

$\mathrm{S}$ : "Itu Bu, yang atas koma nya dihilangkan dikali 10, jadi yang bawah juga dikali 10."

P : "Oh bisa begitu caranya?"

$\mathrm{S}$ : "Iya $\mathrm{Bu}$, saya taunya seperti itu."

P : "Oh gitu... kalo 420.000 ditambah 300.000 hasilnya berapa?"

S : "hmm,, bentar bu, 720,000 kan Bu?"

P : "Iya, betul, tapi kamu jawabnya di sini 450.000?"

$\mathrm{S}$ : "hehe,, iya $\mathrm{Bu}$ saya kurang teliti soalnya buru-buru mengerjakannya."

Berdasarkan petikan wawancara di atas, diketahui bahwa penyebab subyek melakukan kesalahan dalam menjawab soal nomor 2 adalah miskonsepsi dalam mengartikan persentase bunga, terburu-buru dalam mengerjakan dan kekurangtelitian siswa dalam mengerjakan soal cerita matematika.

\section{c. Jawaban Soal No 3:}

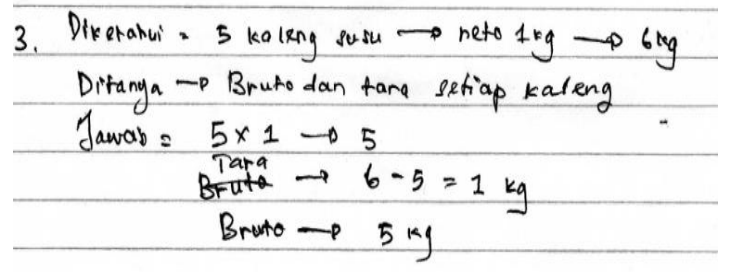

\section{Analisis kesalahan}

Kesalahan yang dilakukan oleh subyek 3 adalah tidak dapat mengubah informasi yang diberikan ke dalam ungkapan matematika, tidak menuliskan rumus dan kesimpulan dari pertanyaan.

\section{Wawancara}

P : "Lynda, bruto itu apa?"

$\mathrm{S}$ : "Berat seluruh Bu."

P : "Tapi lynda paham tidak dengan maksud soal?"

S : "Bingung, Bu."

Berdasarkan petikan wawancara di atas, diketahui bahwa penyebab subyek melakukan kesalahan dalam menjawab soal nomor 3 adalah tidak memahami maksud soal sehingga kebingungan dalam mengambil langkah penyelesaian.

Kesalahan dan penyebab kesalahan dalam menyelesaikan soal cerita matematika adalah:

1. Siswa melakukan kesalahan mengubah informasi yang diberikan ke dalam ungkapan matematika seperti yang dilakukan oleh subyek 2 pada soal nomor 1 yakni menerjemahkan $\quad 1 / 10 \quad$ dari 
sekarung beras yang diartikan 1/10 dari harga. Dari hasil wawancara penyebab subyek 2 salah dalam mengartikan 1/10 dari sekarung beras karena siswa tidak memperhatikan maksud soal. Guru kurang memberikan permasalahan yang berkaitan dengan kehidupan sehari-hari. Permasalahan yang diberikan cenderung bersifat prosedural sehingga siswa kurang memiliki keterampilan dalam melakukan pemecahan masalah yang diberikan.

2. Kesalahan tidak dapat menentukan rumus yang harus digunakan untuk menyelesaikan masalah. Berdasarkan hasil wawancara diketahui bahwa penyebab kesalahan dalam menuliskan rumus adalah karena lupa rumus apa yang akan digunakan dalam menyelesaikan masalah. Siswa cenderung hanya menghafal rumus yang diberikan oleh guru sehingga siswa cepat lupa dengan rumus yang sudah diberikan.

3. Kesalahan miskonsepsi pada diri siswa misalnya salah dalam konsep memahami persentase bunga, seperti pada subyek 3 yang salah memahami konsep persen ke dalam pecahan biasa. Siswa tersebut menganggap bahwa $12,5 \%$ itu sama dengan 125/10.

4. Fakta menarik juga dilakukan oleh subyek 2 dalam memahami konsep bunga perbulan jika diketahui pertahun. Subyek 2 memahami bahwa apabila persentase bunga diketahui pertahun maka yang dikerjakan adalah mengurangkan persentase bunga dengan 12. Yang diartikannya dikurangi 12 bulan. Berdasarkan wawancara dengan subyek 2 penyebabnya adalah kurang pahamnya dalam menghitung bunga perbulan jika diketahui pertahun. Kurang pahamnya siswa yang disebabkan pula di dalam pembelajaran kurang diberikan soal-soal yang bervariasi sehingga ketika siswa diberikan soal yang berbeda siswa tidak dapat menjawab dengan benar.

5. Kesalahan dalam menafsirkan solusi, seperti yang dilakukan subyek 1 yang menjawab pertanyaan dalam persen sedangkan yang ditanyakan soal dalam rupiah. Berdasarkan hasil wawancara diketahui subyek melakukan kesalahan karena tidak memperhatikan apa yang ditanyakan dalam soal.

6. Hampir sebagian siswa tidak menuliskan kesimpulan. Berdasarkan hasil wawancara penyebab kesalahan yang dilakukan siswa adalah siswa cenderung ingin menyingkat jawaban dan tidak terbiasa dalam menuliskan kesimpulan dari suatu jawaban. 
7. Kesalahan dalam perhitungan, seperti yang dilakukan subyek 3. Berdasarkan wawancara dengan subyek 3 penyebab kesalahan yang dilakukan karena terburu-buru dan kekurangtelitian dalam melakukan perhitungan.

\section{SIMPULAN DAN SARAN}

Berdasarkan pembahasan diperoleh kesimpulan sebagai berikut.

a. Siswa salah mengubah informasi yang diberikan ke dalam ungkapan matematika karena siswa tidak memperhatikan maksud soal.

b. Kesalahan tidak dapat menentukan rumus yang harus digunakan untuk menyelesaikan masalah karena lupa rumus apa yang akan digunakan dalam menyelesaikan masalah. Siswa cenderung hanya menghafal rumus yang diberikan oleh guru sehingga siswa cepat lupa dengan rumus yang sudah diberikan.

c. Kesalahan dalam aspek konsep karena telah terjadi miskonsepsi pada diri siswa.

d. Kesalahan dilakukan oleh subyek 2 dalam memahami konsep bunga perbulan jika diketahui pertahun. Subyek 2 memahami bahwa apabila persentase bunga diketahui pertahun maka yang dikerjakan adalah mengurangkan persentase bunga dengan 12 .
Penyebabnya karena kurang pahamnya dalam menghitung bunga perbulan jika diketahui pertahun dan juga di dalam pembelajaran kurang diberikan soal-soal yang bervariasi sehingga ketika siswa diberikan soal yang berbeda siswa tidak dapat menjawab dengan benar.

e. Kesalahan dalam menafsirkan solusi karena tidak memperhatikan apa yang ditanyakan dalam soal.

f. Hampir sebagian siswa tidak menuliskan kesimpulan karena siswa cenderung ingin menyingkat jawaban dan tidak terbiasa dalam menuliskan kesimpulan.

g. Kesalahan dalam perhitungan karena terburu-buru dan kurang teliti dalam melakukan perhitungan.

Berdasarkan kesimpulan pada penelitian ini, disarankan sebagai berikut.

1. Guru sebaiknya lebih menekankan pada proses memahami masalah sehingga siswa mampu menggunakan informasi diberikan dalam melakukan pemecahan masalah dengan baik.

2. Guru sebaiknya lebih sering memberikan soal yang menuntut penalaran berfikir siswa dalam memecahkan suatu permasalahan sehingga tidak hanya terfokus pada keterampilan prosedural yang dilakukan siswa. 
ISSN 2442-5419 Vol. 4, No. 2 (2015) 42-52

3. Guru sebaiknya menuntun siswa untuk selalu memeriksa kembali hasil pengerjaan yang dilakukan agar dapat meminimalisir kesalahan yang dibuat oleh siswa.

\section{DAFTAR PUSTAKA}

Carraher, D.E. 2008. "Beyond blaming the victim and standing in awe of noble savages: a response to Revisiting Lave's cognition in practice". Journal of Educational in Mathematics. Vol. 69. No. 1.

Dewiyani. 2008. Mengajarkan Pemecahan Masalah dengan Menggunakan Langkah Polya. Stikom Jurnal. Vol.12. No 2.

Hudojo, Herman. 2005. Pembelajaran Matematika. Malang: Universitas Negeri Malang.
Putri W, Mella. 2008. Analisis Kesulitan Menyelesaikan Soal Cerita Pada Pelajaran Matematika Kelas VII Semester Ganjil SMP Tri Sukses Natar Tahun Ajaran 2008/2009.

Skripsi. Lampung: Unila.

Soedjadi. 2000. Kiat Pendidikan Matematika di Indonesia. Jakarta: Dikti.

Uno, Hamzah B. 2011. Model Pembelajaran Menciptakan Proses Belajar Mengajar yang Kreatif dan Efektif. Jakarta: Bumi Aksara.

Wijaya, Ariyadi. 2012. Pendidikan Matematika Realistik. Yogyakarta: Graha Ilmu. 